\title{
Individual variability of mytimycin gene expression in mussel
}

\author{
Franck Cantet $^{\mathrm{a}, 1}$, Mylène Toubiana ${ }^{\mathrm{a}}$, Maria-Giovanna Parisi ${ }^{\mathrm{b}}$, Molruedee Sonthi ${ }^{\mathrm{a}, 2}$, Matteo Cammarata ${ }^{\mathrm{b}}$, \\ Philippe Roch ${ }^{\mathrm{a}, *}$
}

${ }^{a}$ Ecologie des Systèmes Marins et Côtiers (EcoSym) UMR5119, Université Montpellier 2-CNRS, cc 093, place E. Bataillon, F-34095 Montpellier cedex 05, France

${ }^{\mathrm{b}}$ Marine Immunobiology Laboratory, University of Palermo, Via Archirafi 18, 90123 Palermo, Italy

\section{A R T I C L E I N F O}

\section{Article history:}

Received 9 March 2012

Received in revised form 18 June 2012

Accepted 19 June 2012

Available online 29 June 2012

\section{Keywords:}

Antifungal

Antimicrobial

Gene expression

Challenge

Innate immunity

\begin{abstract}
A B S T R A C T
The antifungal peptide mytimycin (MytM) is synthesized by hemocytes of the Mediterranean mussel, Mytilus galloprovincialis. In addition to sequence and gene structure diversities previously reported from pooled hemocytes, the present report focused on the expression of mytm gene in individual M. galloprovincialis, before and after challenge. Within untreated mussel, MytM mRNA was observed by ISH in about $42 \%$ of circulating hemocytes, characterized by large, diffuse nucleus. Injection with Fusarium oxysporum increased such percentage, but in only some of the mussels. Similarly, MytM gene expression increased after injection in only some of the mussels, as measured by qPCR. Responders and not responders are common evidence in any given population of organisms. Nevertheless, even if the use of proper pool size selection has been practised to find out and evaluate the most common response trends, individual analyses must be regarded as optimal.
\end{abstract}

(c) 2012 Elsevier Ltd. All rights reserved.

\section{Introduction}

Several bivalve functions and/or gene expressions showed extended variability of responses according to environmental stressors (reviewed by [11]). When addressing to mussels, physiological responses were routinely measured on pools of 8-10 individuals to minimize such not understood individual variability $[2,4,14]$. Moving to genomic structure analysis, it was only recently that the nucleotide sequences of the antimicrobial peptides, mytilin B [18] and myticin C [7], were reported as different from one mussel to another. In addition, intra-individual diversity of myticin C [7], C1q domain-containing protein [10] and fibrinogen-related proteins (FREPs) [22] were observed. We previously reported on polymorphism of the antifungal peptide mytimycin (MytM) from the Mediterranean mussel, Mytilus galloprovincialis, with the existence of 16 nucleotide sequences

Abbreviations: AMP, Antimicrobial peptide; ISH, In situ hybridization; MytM, Mytimycin; qPCR, Real-time or quantitative PCR.

* Corresponding author. Tel.: +330 467144 712; fax: +330 467144673.

E-mail address: Philippe.Roch@univ-montp2.fr (P. Roch).

1 Present address: Centre d'études d'agents Pathogènes et Biotechnologies pour la Santé (CPBS) UMR 5236, CNRS 1919 route de Mende, 34293 Montpellier Cedex 5, France.

2 Present address: Faculty of Marine Technology, Burapha University, 57 M1 Chonprathan Road, Khamong, Thamai, Chanthaburi 22170, Thailand. translated into 6 amino acid sequences [23]. Among various challenges with bacteria and fungi, only injection of Fusarium oxysporum was able to increase the mytm gene expression with maximum expression observed $9 \mathrm{~h}$ post-challenge, as measured on pools of hemocytes from 10 mussels [24]. In addition to such analyses performed on pools, the present report focused on the expression of MytM gene in individual M. galloprovincialis, before and after injection with the filamentous fungus, F. oxysporum. Two techniques have been applied, (i) qPCR quantifying MytM mRNA and, (ii) ISH visualizing and counting the MytM-expressing hemocytes.

\section{Material and methods}

\subsection{Mussels, fungus, in vivo challenge and sampling}

Adult mussels, $M$. galloprovincialis (6-7 cm shell length) from Palavas (Mediterranean Sea-France), filamentous fungus, F. oxysporum, injection and hemocyte collection 9h post-injection corresponding to maximum MytM expression, were as previously reported [24]. Posterior adductor muscle have been dissected $9 \mathrm{~h}$ after injection, immediately immerged in liquid nitrogen and grounded into $1 \mathrm{ml}$ of Trizol. For in situ hybridization (ISH), freshly collected hemocytes have been fixed by overnight incubation in $10 \%$ neutral buffer formalin (NBF: $46 \mathrm{mM} \mathrm{Na} \mathrm{HPO}_{4}, 30 \mathrm{mM}$ $\mathrm{NaH}_{2} \mathrm{PO}_{4}, 3.7 \%$ formaldehyde in distilled water, $\mathrm{pH} 7$ ), washed by 
15 min centrifugation at $800 \times \mathrm{g}, 4{ }^{\circ} \mathrm{C}$ and deposited onto polylysine coated glass slides [6].

\subsection{RNA extraction, reverse transcription and $q P C R$}

Total RNA has been extracted according to the RNeasy Mini kit protocol (Qiagen). Quantity has been evaluated on NanoDrop ND1000 and quality checked by electrophoresis on Nano LabChip (Agilent Technologies). First strand cDNA synthesis has been performed on $1 \mu \mathrm{g}$ of total RNA using hexaprimers (Invitrogen) and murine leukemia virus reverse transcriptase (Promega). Primers for house keeping gene 28S rRNA were from [19]. Primers for MytM mRNA were from [24] and designed within conserved sequences regarding mussels from Palavas. Measurement of gene expression using SYBR Green qPCR technique on LightCycler 480 384-wells plate, and quantification by the Livak $2^{-\Delta \Delta \mathrm{CT}}$ method expressed as $x$-fold the expression adjusted to 1 in untreated, have been previously reported [24]. A threshold of 4 times the expression in untreated was considered as the limit for significant up-regulation [13]. Statistical tests related to low number of assays, used the Mann-Whitney test. $P$ values lower than 0.05 revealed significant differences.

\subsection{In situ hybridization (ISH) on hemocytes}

MytM amplicon has been synthesized by PCR using qPCR primers and GoTaq DNA polymerase (Promega), then cloned using pCR II-TOPO plasmid (Invitrogen). Such amplicon did not discriminate between MytM variants and covered all the different forms. Antisense and sense digoxigenin labeled riboprobes have been synthesized from the plasmid using the digoxigenin-RNA Labeling Kit SP6/T7 (Roche). Proteinase-K (Sigma) treatment, hybridization with $200 \mathrm{ng} / \mu \mathrm{l}$ denaturized riboprobes, incubation with sheep antidigoxigenin Fab fragments (Roche) conjugated to alkalinephosphatase, incubation in nitroblue tetrazolium/5-bromo-4chloro-3-indolylphosphate (NBT/BCIP) solution (Promega), counterstaining with Bismarck Brown Y (Sigma), dehydration and mounting have been previously reported for lysozyme [13]. Observations, counting and pictures have been done with a photonic microscope Leica DMR (Leica Microsystems, WetzlarGermany). Statistics as in Section 2.2.

\section{Results and discussion}

\subsection{Quantification MytM gene expression}

\subsubsection{In circulating hemocytes}

Nine hours after injection with F. oxysporum, five mussels did not show significantly different stimulation compared to untreated $(p=0.73)$ (Fig. 1). These mussels, nos. 1, 3-5 and 9, with expression below the threshold of 4 , were considered as non-responders. On the opposite, folds of expression dramatically increased in 4 of the challenged mussels with a mean value of $36.6 \pm 17.3$, significantly different from untreated $(p<0.001)$ and from the five nonresponders $(p<0.05)$. Obviously these four mussels responded to the challenge by increasing the expression of MytM gene; they were qualified as responders. The present study involved only a restricted number of mussels. Meanwhile, it appeared clearly that only some mussels reacted to the injection with $F$. oxysporum by increasing the expression of MytM gene.

In all the previously reported negative effect of stress and injections on AMP [5,24], lysozyme [13] and HSP70 [4] gene expressions measured on pools, one can hypothesized that we missed the few reacting mussels. Even if such treatments resulted in up-regulation in some mussels, such effect was minimum and

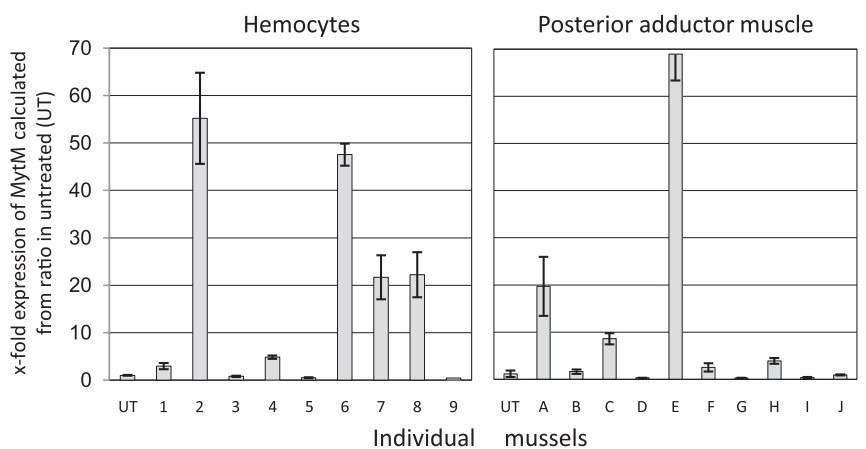

Fig. 1. Relative quantification of MytM mRNA in circulating hemocytes (left panel) from 9 mussels (1-9) and in posterior adductor muscle (right panel) from 10 mussels (A-J), $9 \mathrm{~h}$ after challenge with one injection of $10^{4} \mathrm{~F}$. oxysporum spores into the posterior adductor muscle. Quantifications as $\mathrm{x}$-fold expression compared to 1 in untreated (UT). Values are from the arithmetic mean of 5-7 replicates \pm SD (bars) of individual mussel, except for UT which values are from pools of 10 individuals each. Note that only some mussels presented an up-regulation of MytM gene expression: 4 regarding hemocytes and 3 regarding muscle.

not sufficient to increase the fold expression of the pool to a value significantly different from untreated.

\subsubsection{In posterior adductor muscle}

Although reverse transcriptions have been always performed with $1 \mu \mathrm{g}$ of total RNA, differences in MytM mRNA quantifications we measured might result from variable numbers of circulating MytM gene expressing hemocytes. Indeed, we previously reported that lysozyme-expressing hemocytes accumulated within sinuses of the posterior adductor muscle where injection took place. Optical observation of ISH revealed enlarged sinuses blocked with aggregated hemocytes [13]. Similarly, considering MytM gene expressing hemocytes would be trapped in muscle sinuses, present quantification of MytM mRNA from circulating hemocytes addressed principally non-MytM gene expressing sub-population of hemocytes. Meanwhile, the needle used for sampling might extract variable numbers of MytM gene expressing sinus-adhering hemocytes, leading to variability in the detected levels of MytM transcripts. To control such hypothesis, MytM transcript levels have been quantified from RNA extracted from the entire posterior adductor muscle $9 \mathrm{~h}$ after injection with $F$. oxysporum (Fig. 1). Among the 10 dissected muscles, 7 did not show significant stimulation of MytM gene expression $(1.41 \pm 1.37, p=0.6)$ compared to untreated. On the opposite, three mussels presented significant upregulation ranged from $8.6 \pm 1.2(p<0.001)$ to $68.9 \pm 5.6$ $(p<0.001)$.

Consequently, the variability of MytM gene expression measured in hemocytes was not due to the sampling process, but to the fact that not all the mussels reacted to the challenge with F. oxysporum. As we tested only 9 and 10 mussels, any percentage on reacting versus non-reacting mussels will not be valid. In addition, we cannot exclude that technical injection problems resulted in ineffective or partially effective fungal injections, explaining absence or erratic responses. We previously reported that injection of $10^{3} \mathrm{~F}$. oxysporum spores did not significantly upregulated the MytM gene expression [24]. Only larger batch of injected mussels might confirm the existence of non-responders.

\subsection{Cytology of MytM-expressing hemocytes}

Optical microscopy observation of hemocytes from untreated mussels revealed the presence of two cell categories mainly based on nucleus aspect: small, dense with condensed chromatin versus 


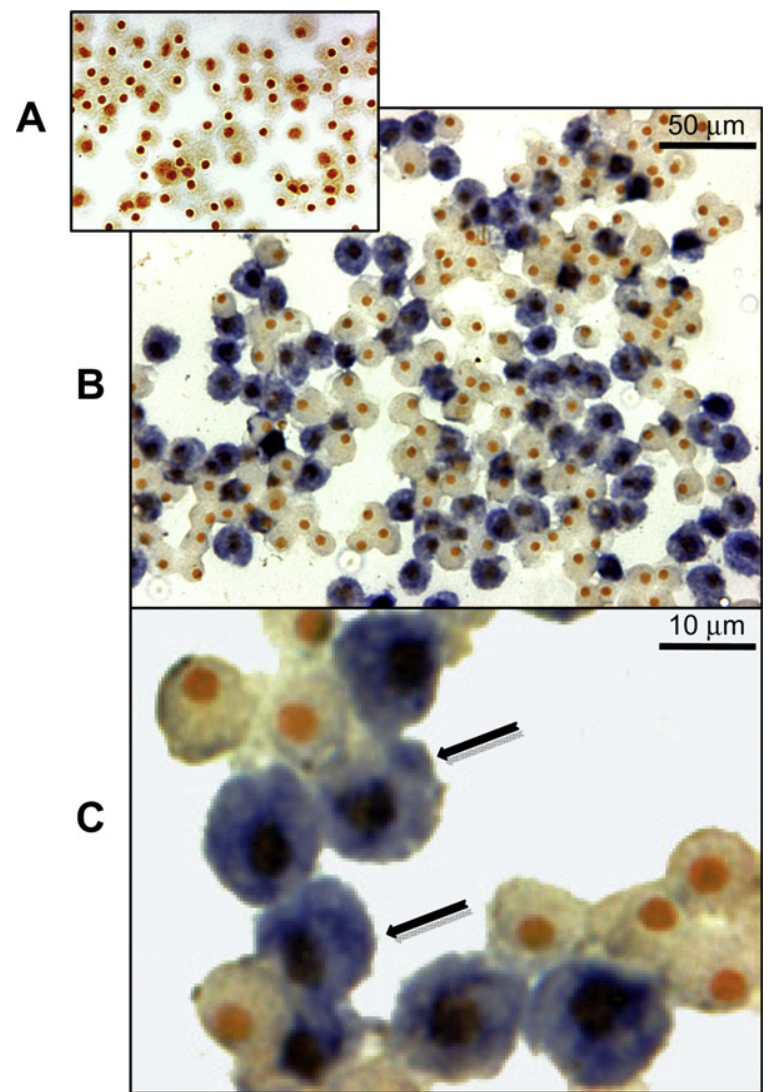

Fig. 2. Microscopic observations of hemocytes from untreated mussels observed after labeling in ISH with MytM mRNA sense probe (A) and with antisense probe (B and C), counterstained with Bismarck brown. Note that only some hemocytes were stained in blue revealing the presence of MytM mRNA. Dark-blue spots within the cytoplasm (arrows in C) revealed concentrations probably related to ribosomes. (For interpretation of the references to colour in this figure legend, the reader is referred to the web version of this article.)

large, diffuse nucleus content (Fig. 2). Only hemocytes with large nucleus were labeled, including nucleus and cytoplasm suggesting trafficking of MytM mRNA. Decongested nucleus is a typical sign of intense transcription and one can hypothesized that observed decongestion was correlated to MytM gene expression. In addition, dark-blue spots within the cytoplasm suggested accumulation of MytM mRNA into ribosomes. Cytoplasm of non-labeled densenucleus hemocytes did not contain granules, putatively identifying these hemocytes as hyalinocytes.

Numerous studies on mussel hemocyte population started in 1977 [16]. General assertion was on two cell categories based on their granule content: (i) granule-free hyalinocytes and (ii) granulocytes further subdivided according to granule size [21,25]. Staining capacities resulted also in 2 cell types: (i) basophils and (ii) eosinophils $[3,8,20]$. More sophisticated techniques, such labeling with monoclonal antibodies, revealed 3 groups: (i) basophilic granulocytes, (ii) basophilic granular and hyaline cells and (iii) eosinophilic granular cells [9]. Finally, single cell contrast microscopy time-lapse motility imaging combined with flow cytometry and cell volume determination revealed fast modifications of hemocyte aspect in vitro, rendering uncertain classification based on morphology [12]. As a consequence, classification and lineage are still in debate.

In the present report, non-expressing MytM cells appeared belonging to hyalinocytes, on the opposite of MytM gene expressing cells, which included all the granulocytes. But we cannot exclude that some hyalinocytes have been also labeled as ISH treatments and the blue coloration masked cytoplasm details. We previously demonstrated that injection of bacteria into M. galloprovincialis resulted in the synthesis of lysozyme mRNA into hyalinocytes [13] and that hyalinocytes are also involved in bacterial clearance [17]. In addition, and even if less efficient than granulocytes, hyalinocytes were reported as capable of phagocytosis, at least in vitro [1].

Finally, we did not notice morphological difference between ISH treated hemocytes collected in untreated mussels and collected $9 \mathrm{~h}$ after injection with $F$. oxysporum (not illustrated).

\subsection{Percentages of hemocytes labeled by MytM mRNA}

Aliquots of hemocytes from the mussels previously used for qPCR have been incubated with MytM mRNA probe and observed in optical microscopy (Fig. 3). Within the nine untreated mussels, mean percentage of labeled hemocytes was $42.8 \pm 1.4 \%$. Previous observations performed on pools reported that granulocytes accounted for $60 \%$ [20] to $80 \%$ [17] of the Mytilus hemocytes. But granulocytes constituted a heterogeneous sub-population
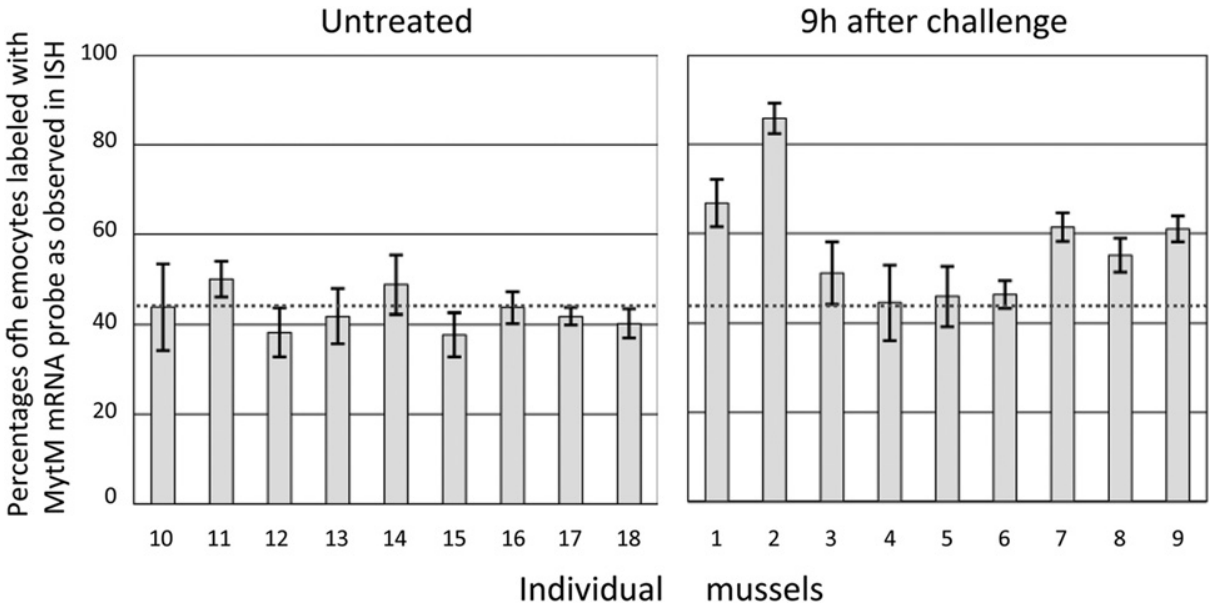

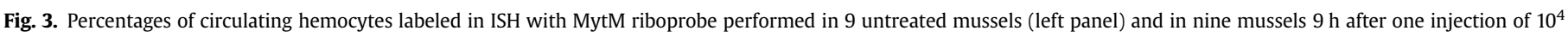

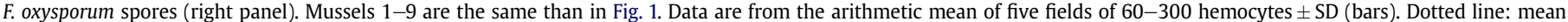

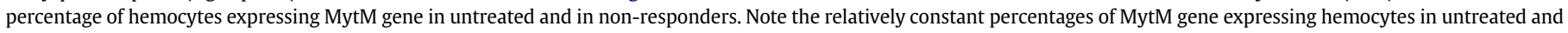
the increased percentages in five of the challenged mussels. 
including about $2 / 3$ of small cells containing small granules and $1 / 3$ of large cells containing large granules [17]. Actually, the counterstaining with Bismarck brown used in this study did not discriminate. Granulocytes have been previously reported as containing defensin and mytilin [15]. Using polyclonal antibodies, defensin peptide was observed in $48 \%$ of the hemocytes whereas mytilin was present in $69 \%, 32 \%$ of hemocytes containing simultaneously the two AMPs. In addition, lysozyme mRNA has been observed in only some granulocytes from untreated mussels but without precision of percentage [13].

After being challenged with $F$. oxysporum, four mussels did not present significant increased percentage of labeled hemocytes with a mean value of $46.9 \pm 1.4 \%$ ( $p=0.11$ ) (Fig. 3 ). On the opposite, 5 out of the 9 challenged mussels showed a mean percentage significantly different from the previous one $(66.0 \pm 5.2 \%, p<0.05)$. Cytological observation did not reveal difference between these two groups: in both cases, unstained cells were hyalinocyte-like hemocytes. We must highlight that no correlation existed between qPCR quantification and the number of labeled hemocytes as observed in ISH: mussels no. 1, 6 or 9, for instance. We previously demonstrated that total number of hemocytes dramatically decreased $3 \mathrm{~h}$ post-injection with bacteria and returned to background at 6-9 h [17]. To overcome eventual bias due to different numbers of collected hemocytes following injection with F. oxysporum, we controlled that the number of collected hemocytes was approximately the same from one challenged mussel to another, whereas reverse transcriptions were performed always on $1 \mu \mathrm{g}$ of total RNA.

In conclusion, after the discovery of several AMP families and the existence of extended polymorphism on M. galloprovincialis, from pools, then on individuals, we report here different behaviour of individual mussels towards the same challenge. The extended individual variability observed here regarding MytM expression, already suggested in previous reports by large confidence limits of different activities measured in pools, demonstrated that to consider only one criterion, measured in a restricted number of animals, is not adequate to quantify the immune statue of a population.

\section{Acknowledgements}

This work was partially funded by the EU program BIVALIFE (KBBE-2010-266157), the PICS no. 5197 between CNRS and the University of Palermo-Italy, and the INTERLINK program from the Italian Ministry of Education. Authors are grateful to Professor Guy Charmantier for access to Leica microscope and to Romain Gros for technical assistance.

\section{References}

[1] Cajaraville MP, Pal SG. Morphofunctional study of the haemocytes of the bivalve mollusc Mytilus galloprovincialis with emphasis on the endolysosomal compartment. Cell Structure and Function 1995;20:355-67.

[2] Canesi L, Viarengo A, Leonzio C, Filippelli M, Gallo G. Heavy metals and glutathione metabolism in mussel tissues. Aquatic Toxicology 1999;46:67-76.

[3] Carballal M, Lopez M, Azevedo C, Villalba A. Hemolymph cell types of the mussel Mytilus galloprovincialis. Disease of Aquatic Organisms 1997;29: 127-35.
[4] Cellura C, Toubiana M, Parrinello N, Roch P. HSP70 gene expression in Mytilus galloprovincialis hemocytes is triggered by moderate heat shock and Vibrio anguillarum, but not by V. splendidus or Micrococcus lysodeikticus. Developmental \& Comparative Immunology 2006;30:984-97.

[5] Cellura C, Toubiana M, Parrinello N, Roch P. Specific expression of antimicrobial peptide and HSP70 genes in response to heat-shock and several bacterial challenges in mussels. Fish and Shellfish Immunology 2007;22: 340-50.

[6] Corporeau C, Auffret M. In situ hybridisation for flow cytometry: a molecular method for monitoring stress-gene expression in hemolymph cells of oysters. Aquatic Toxicology 2003;64:427-35.

[7] Costa MM, Dios S, Alonso-Gutierrez J, Romero A, Novoa B, Figueras A. Evidence of high individual diversity on myticin $\mathrm{C}$ in mussel (Mytilus galloprovincialis) Developmental \& Comparative Immunology 2009;33:162-70.

[8] Dyrynda EA, Law RJ, Dyrynda PEJ, Kelly CA, Pipe RK, Graham KL, et al Modulations in cell-mediated immunity of Mytilus edulis following the "Sea Empress" oil spill. Journal of the Marine Biological Association of the United Kingdom 1997a;77:281-4.

[9] Dyrynda EA, Pipe RK, Ratcliffe NA. Sub-populations of haemocytes in the adult and developing marine mussel, Mytilus edulis, identified by use of monoclonal antibodies. Cell and Tissue Research 1997b;289:527-36.

[10] Gestal C, Pallavicini A, Venier P, Novoa B, Figueras A. MgC1q, a novel C1qdomain-containing protein involved in the immune response of Mytilus galloprovincialis. Developmental and Comparative Immunology 2010;34: 926-34.

[11] Giron-Perez MI. Relationships between innate immunity in bivalve molluscs and environmental pollution. Invertebrate Survival Journal 2010;7:149-56.

[12] Le Foll F, Rioult D, Boussa S, Pasquier J, Dagher Z, Leboulenger F. Characterisation of Mytilus edulis hemocyte subpopulations by single cell time-lapse motility imaging. Fish and Shellfish Immunology 2010;28:372-86.

[13] Li H, Parisi MG, Toubiana M, Cammarata M, Roch P. Lysozyme gene expression and hemocyte behaviour in the Mediterranean mussel, Mytilus galloprovincialis, after injection of various bacteria or temperature stresses. Fish and Shellfish Immunology 2008:25:143-52.

[14] Mitta G, Hubert F, Noel T, Roch P. Myticin, a novel cysteine-rich antimicrobia peptide isolated from haemocytes and plasma of the mussel Mytilus galloprovincialis. European Journal of Biochemistry 1999;265:71-8.

[15] Mitta G, Vandenbulcke F, Noel T, Romestand B, Beauvillain JC, Salzet M, et al. Differential distribution and defence involvement of antimicrobial peptides in mussel. Journal of Cell Science 2000;113(Pt 15):2759-69.

[16] Moore MN, Lowe DM. The cytology and cytochemistry of the hemocytes of Mytilus edulis and their response to experimentally injected carbon particles. Journal of Invertebrate Pathology 1977;29:18-30.

[17] Parisi MG, Li H, Jouvet LB, Dyrynda EA, Parrinello N, Cammarata M, et al. Differential involvement of mussel hemocyte sub-populations in the clearance of bacteria. Fish and Shellfish Immunology 2008;25:834-40.

[18] Parisi MG, Li H, Toubiana M, Parrinello N, Cammarata M, Roch P. Polymorphism of mytilin B mRNA is not translated into mature peptide. Molecular Immunology 2009;46:384-92.

[19] Parisi MG, Toubiana M, Mangano V, Parrinello N, Cammarata M, Roch P. MIF from mussel: coding sequence, phylogeny, polymorphism, 3D model and regulation of expression. Developmental and Comparative Immunology 2012; 36:688-96.

[20] Pipe RK, Farley SR, Coles JA. The separation and characterisation of haemocytes from the mussel Mytilus edulis. Cell and Tissue Research 1997;289: 537-45.

[21] Pipe RK. Differential binding of lectins to haemocytes of the mussel, Mytilus edulis. Cell and Tissue Research 1990;261:261-8.

[22] Romero A, Dios S, Poisa-Beiro L, Costa MM, Posada D, Figueras A, et al. Individual sequence variability and functional activities of fibrinogen-related proteins (FREPs) in the Mediterranean mussel (Mytilus galloprovincialis) suggest ancient and complex immune recognition models in invertebrates. Developmental and Comparative Immunology 2011;35:334-44.

[23] Sonthi M, Toubiana M, Pallavicini A, Venier P, Roch P. Diversity of coding sequences and gene structures of the antifungal peptide Mytimycin (MytM) from the Mediterranean Mussel, Mytilus galloprovincialis. Marine Biotechnology (NY) 2011;13:857-67.

[24] Sonthi M, Cantet F, Toubiana M, Trapani MR, Parisi MG, Cammarata M, et al. Gene expression specificity of the mussel antifungal mytimycin (MytM). Fish and Shellfish Immunology 2012;32:45-50.

[25] Wang Y, Hu M, Chiang MW, Shin PK, Cheung SG. Characterization of subpopulations and immune-related parameters of hemocytes in the greenlipped mussel Perna viridis. Fish and Shellfish Immunology 2012;32: $381-90$. 